\title{
Congress may block stem-cell research
}

[WASHINGTON] Seventy-seven anti-abortion members of Congress have written two letters to the Secretary of Health and Human Services, Donna Shalala, criticizing her for the recent decision to allow federal funding of research using human embryonic cells.

In a letter from members of the House of Representatives, 62 Republicans and eight Democrats call on Shalala to reverse the decision. They warn that if Harold Varmus, the director of the National Institutes of Health $(\mathrm{NIH})$, proceeds as planned to fund the research, the NIH will be in violation of "both the letter and spirit" of the law banning federal funding for research in which human embryos are harmed or destroyed.

In a separate letter, seven Republican Senators accuse Shalala of a "unilateral attempt" to "effectively undermine congressional intent, by circumventing the current federal funding ban on embryo research".

Last month, Harriet Rabb, the general counsel of the Department of Health and Human Services (DHHS), issued a legal opinion that stem-cell research is exempt from the ban (see Nature 397, 185; 1999). Rabb argued that because stem cells are not 'organisms' as defined in the law, federally funded scientists can work with them, even though the extraction of stem cells from embryos (which requires their destruction) cannot be publicly funded.

Varmus then announced that the NIH would begin funding stem-cell research in the coming months, under careful ethical supervision. But in a letter sent to Shalala on 11 February, the House lawmakers describe
Rabb's memo as "a carefully worded effort to justify transgressing" the ban on embryo research.

The letter's authors include the House majority leader, Dick Armey (Republican, Texas), the majority whip, Tom DeLay (Republican, Texas), and the chairman of the House Judiciary Committee, Henry Hyde (Republican, Texas).

Signatories to the letter sent by senators on 12 February include the majority whip, Don Nickles (Republican, Oklahoma). Laurie Boeder, a DHHS spokeswoman, says that Shalala will respond "in a timely fashion". She adds that Varmus has emphasized that, because of the potential benefits of the research for patients with a wide variety of diseases, "it's important for us to look into how we can appropriately fund federal research using existing stem cells".

But one biomedical lobbyist says "the political environment has changed dramatically". The letters "alert everybody that this group of people is going to fight very hard the ability to do stem-cell research under the existing statute".

The embryo research ban, first enacted in the 1996 fiscal year and renewed by Congress each year as part of annual spending bills that fund the NIH, bars federal support for "research in which a human embryo or embryos are destroyed".

The letter-writers claim that Rabb makes a specious distinction by reading the law narrowly to apply only to the act of destroying embryos, and not more broadly to include any research that depends on their destruc- tion. "We prohibited the funding of research projects in which the lethal dissection or harmful manipulation of living human embryos is a necessary prerequisite," wrote the House members.

In testimony to the Senate in January, Varmus said he was unsure whether stem cells derived from the inner cell mass of the blastocyst might come together in culture to form an embryo. If so, the senators argue, then stem-cell research itself, regardless of issues surrounding their extraction, would be in direct violation of the embryo research ban.

Senator Arlen Specter (Republican, Pennsylvania), chair of the Senate subcommittee that funds the NIH and a strong supporter of stem-cell research, told the New York Times that the House letter puts proponents of the research "in very deep water".

Varmus plans to convene a subcommittee of his advisory committee to develop guidelines specifying what stem-cell work NIH can support. The subcommittee will also suggest a mechanism for an extra layer of review for stem-cell research proposals.

But this would become moot if Congress widens the ban to cover stem-cell research relying on the destruction of embryos. Jay Dickey (Republican, Arkansas), principal House author of the existing ban, issued a statement last week pointing out that the research relies on stem cells from embryos that were killed by having their stem cells removed. "This is precisely the kind of research for which we intended to ban, and did ban, federal funding." Meredith Wadman

\section{Co-dis coverer of evidence for quarks killed in diving accident}

[воSтоN] Henry Kendall — professor of physics at the Massachusetts Institute of Technology (MIT), Nobel laureate and a tireless political activist — died last week while scuba diving in a Florida lake. He was 72 years old.

Kendall was an experienced deep-sea diver who had written books on the subject and designed underwater cameras. He had been photographing Wakulla Springs, the world's largest freshwater springs, accompanying a team of divers from the National Geographic Society.

Members of this team found him unconscious in shallow water a few feet from shore and took him to hospital, where he was pronounced dead on arrival. The cause of death is unknown, but his diving equipment is being tested to see if it malfunctioned.

Kendall received the Nobel prize for physics in 1990 with his MIT colleague Jerome Friedman and Richard Taylor of

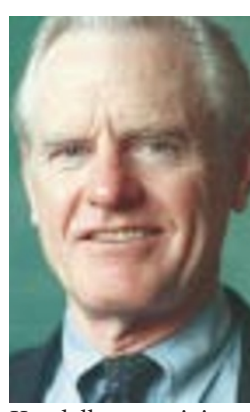

Kendall: an activist as well as an academic.

their interior consistent with the quark model independently proposed in 1964 by Murray Gell-Mann and George Zweig. The finding paved the way for the Standard Model of physics.

Kendall will also be remembered for his activities on many political and environmental fronts. A co-founder of the Union of Concerned Scientists (UCS), and its chairman since 1973, he was one of the first scientists to reveal safety flaws in the design and operation of nuclear power plants. He also warned against an unchecked nuclear arms race, and fought the 'Star Wars' defence initiative and space-based weapons.

Kendall co-authored books on energy policy, arms control, nuclear war and the fallacy of missile defence. More recently, he urged the adoption of measures to curb global warming - a subject on which he briefed President Bill Clinton in 1997.

"He always saw the big picture," says Friedman. Howard Ris, UCS executive director, says that Kendall "firmly believed that scientists could — and should - play an important role in public policy debates. His leadership ... was deeply rooted in the belief that, given accurate and credible information, the public and policymakers would, ultimately, make the right choices about the future."

Steve Nadis 